\title{
Reminiscing in White in Fae Myenne Ng's Bone
}

\begin{abstract}
The article focuses on the representation of whiteness in Fae Myenne Ng's Bone (1993), in particular on how the aesthetic and the socio-historical strata of the novel intersect, how by saturating the imagery of Bone with whiteness, $\mathrm{Ng}$ conveys the first person Chinese American narrator's positionality and the positionality of other Chinese American characters as members of the Chinese American community and members of broader American society. The images involving whiteness compose a kind of the palimpsest overwritten with personal and communal ethnic watermarks as well as repressed, surfacing and semi-articulated history of Leila's family that she channels into the narrative, having engaged in the process of mentally retracing the past events and recovering the material evidence or rather what remains of it and what she believes will lead her to definitive answers. On the level of narrative imagery, whiteness is intricately interwoven with the traumas plaguing the narrator's family. Explicitly, whiteness represents death, mourning, rejection and erasure, entailing marginalization suffered by Chinese Americans because of their non-normative racial and ethnic status. Yet, implicitly, whiteness is also a constituent element of the images which facilitate the process of healing - mainly bones and paper. Narrative imagery involving whiteness contributes to the bridging of the past and the present, forming a bridge between generations, a kind of rivet that allows to at least partly retrieve personal wholeness and recapture the broken promises.
\end{abstract}

\section{Keywords}

Whiteness; Bone; Fae Myenne Ng; paper; bones; mourning

The article focuses on the representation of whiteness in Fae Myenne Ng's Bone (1993). Most of the criticism of the novel has revolved around such issues as subjectivity construction, melancholy, mourning, Chinese American citizenship, Chinatown, suicide and haunting. While in the following exploration of the novel 
I inevitably touch on all of these points, I explicitly examine the representation of whiteness in the narrative, in particular how the aesthetic and the socio-historical strata of the text intersect, how by saturating the imagery of the novel with whiteness, Ng conveys the first person Chinese American narrator's positionality and the positionality of other Chinese American characters as members of the Chinese American community and members of broader American society. Initiating in 1992 contemporary literary whiteness studies and especially the study of whiteness in American literature with her seminal work Playing in the Dark, Toni Morrison claimed that writers "transform aspects of their social grounding into aspects of language" (4) and that "[k]nowledge however mundane and egalitarian plays about in linguistic images and forms cultural practice" (49). Morrison's second statement corresponds closely to the reflections by Filipina American sociologist, Karin Aguilar-San Juan, who wrote in 1994: “Asian American writers tread deliberately, for every image, every phrase is likely to have lasting reverberations throughout the community" (17). Echoing Clifford Geertz's Local Knowledge, Morrison concentrates on the social sphere providing a stimulus for the creation of particular narrative imagery. Aguilar-San Juan shifts the focus to the social ramifications stemming from the imagery of a work - the consequences of narrative strategies for a particular community. Both note a very close overlap of the social and the aesthetic, an overlap that is also very conspicuous in Fae Myenne $\mathrm{Ng}$ 's Bone whose postmodern, eccentric structure contributes to the dispersion of whiteness into a multitude of images, all of which help the first person narrator, Leila, to piece together her narrative.

In the novel whiteness is the explicit and implicit attribute of imagery. The images involving whiteness compose a kind of the palimpsest ${ }^{1}$ overwritten with personal and communal ethnic watermarks as well as repressed, surfacing and semi-articulated history of Leila's family that she channels into the narrative, having engaged in the process of mentally retracing the past events and recovering the material evidence or rather what remains of it and what she believes will lead her to definitive answers. Implicitly, whiteness recurs in the images of bones and paper. Explicitly, Leila identifies whiteness as the color of mourning. During her paper grandafther's funeral ceremony Leila punctiliously throws away anything that approximates the color of whiteness - even a "cellophane wrapping that was colorless" ([1993] 1994: 84). Considering the primary, overt signification of whiteness in the Chinese American community as the color of mourning, one may claim that the prominence of whiteness in the narrative stems from the fact that the whole novel is suffused with the spirit of healing, of trying to recover from traumas plaguing Leila's family - primarily the premature death by suicide of Leila's younger sister - Ona. Ona's death features as the most conspicuous in the tapestry of family's dramas with which individual members of the narrator's family grapple on their own and collectively. In the process of the narrative search for healing, whiteness becomes dispersed into the images which receive positive signification - mostly bones and paper. As in Joy Kogawa's Obasan, instead of 
being merely a symbol of death, bones are first of all a symbol of remembering, a link between the living and the dead.

Paper plays an equivalent role in Bone. Serving mainly as a vehicle for the word, paper is a vital instrument of searching for the truth, of commemoration, communication and legitimization. It is paper and bones that conjure up the most immediate associations of the palimpsest, of uncovering the past and rootedness of Leila's family and the broader Chinese American community. All scraps of paper gathered in Leon's (the narrator's stepfather) suitcase are a vouchsafe against disremembering. Perusing Leon's papers, Leila observes: "All I have are those memories and I want to remember them all .... Remembering the past gives power to the present" (1994: 61, 88-89). For Leon, the paper son, paper has an additional value because "For a paper son paper is blood" (61). Paper sons were Chinese men who bypassed exclusion laws by claiming relation to the men already residing in the United States. The only Chinese who were able to enter the United States were merchants, students and family members of merchants or the Chinese born in the United States and hence American citizens under the auspices of the federal law. Forged birth certificates identified "paper sons" as sons of the above mentioned groups (de Bary Nee 1973: 62). Leon's paper identity card establishes his citizenship and his right to be in the United States. Leila recalls Chinatown ceremonies in honor of paper and the written word. Paper allows Leila to map the grave of her paper grandfather and paper is her pass to the cemetery that is off limits to strangers. A piece of paper with all important information concerning the dead is slipped into the coffin so that "in the case of an earthquake, people would know where the body belonged, where home was" (Ng 1994: 73). Paper helps Leila to gather all the stories of her people and channel them into a history since "knowing the story connects us to a history" (36). Leila's statement echoes the claims of those literary critics who trace certain parallels between fiction writing and historiography since fiction borrows certain techniques from history writing and history in turn can be perceived as a kind of narrative.

\section{Mourning}

The prevailing trope of whiteness in Bone is the trope of mourning. Apart from being directly named as the avatar of mourning in the above-cited passages, whiteness features significantly in the narrative imagery when Leila is told of Ona's death. Looking at her interlocutor and the messenger reporting about Ona's death, Leila visually registers the white elements of the messenger's appearance: "the pale center of her eyes," and a "white gate of teeth," which turn out to be false (136). In response to Ona's death, Leila sits on the toilet and watches the "white waves" of paper pile up at "at her feet" (136). ${ }^{2}$ She also remembers that her mother usually dressed Ona in white and the youngest sister Nina in red. The fact that Ona was dressed in white, the color of mourning, anticipates Ona's 
premature death and the mourning over her. Red, on the other hand, is the color of life in Chinese aesthetics. Unlike Ona, who cannot liberate herself from split loyalties and in the end the stifling atmosphere of Chinatown, Nina has no qualms of conscience about leaving the San Francisco Chinatown and moving to New York. Whiteness once again recurs in connection with Ona's death when Leila draws the reader's attention to the whiteness of her own lips while reliving the moment of Ona's death and reaching the full realization of her sister's passing after she completes the organizing of Ona's funeral and has time to stop and think (153-154). Nina also looks pale, but the whiteness of her face is once again juxtaposed with the red color of her dress, breaking the Chinese cultural code since red is a festive color inappropriate on the occasion of mourning. Leila presents mourning in the San Francisco Chinatown as to a great extent a communal activity. Everyone feels sorry for the Ong family, expressing their sympathy to every family member and extending their offers of help. Chinatown old timers offer gifts, including "white gold in Ona's memory" (118).

The whole novel is an anatomy of Ona's suicide. Looking for healing and closure, Bone, as a postmodern narrative, at the same time gestures towards indeterminacy and open-endedness. Neither the narrator nor any character gives a clear cut answer as to why Ona committed suicide, but the passage cited below probably comes closest to answering this question:

\footnotetext{
Maybe being in the middle, Ona felt more stuck than either Nina or me. I think Ona wanted to be equally divided about her loyalties to Mah and Leon. But in the end Ona felt disappointed by Leon and betrayed by Mah. Why hadn't Leon seen his selfishness? Why hadn't Mah come to Ona's defense? (112)
}

It is Ona that shows the greatest attachment to Chinatown among the Leong sisters. Nina literally displays her distance from the San Francisco Chinatown by moving to New York. Leila manages to maintain her integrity while straddling both sides of the fence. She keeps regularly in touch with her parents, at the same time leading an independent life with her Chinese American husband Mason. Her parents can always count on her, but she does not manifest the same mental dependence on her family that Ona does. Devoting herself by far the most wholeheartedly to her parents, Ona expects the same understanding and commitment when she falls in love with, Osvaldo, the son of her father Leon's former partner, who swindled Leon in the failed laundry business. Instead of support, Leon threatens to renounce Ona if she does not terminate the relationship. Leila's narration renders the intensity of emotions accompanying Ona's affair with Osvaldo. In the atmosphere of emotions reaching fever pitch, no one in the Leong family is detached enough to take a sober-eyed look at the events and to offer support and guidance to Ona. Following Ona's suicide, everyone keeps asking "why," blaming themselves. Leon projects his own sense of guilt on everyone around him. The analysis of Ona's death would not be complete without considering material exigencies and social pressures which the Leong family confronts throughout the 
narrative on account of their Chinese American minority status. Reflecting on his own frustrated expectations, Leon calls America "this lie of a country" because it broke all promises he heard about before arriving in the United States, while he "kept his end of the bargain" (103). "Keep[ing] his end of the bargain" consists mostly in his arduous, poorly remunerated labor. Ona's life is also marked by the drudgery of daily, menial, strenuous labor on a night shift in a restaurant, a job which she needs to reconcile with her studies at the San Francisco State University. Delving into the circumstances of Ona's suicide, Leila notes all of the aforementioned factors, yet at times she refuses to acknowledge that it was a willful act, concluding at one point that "Someone stole Ona. Ona hadn't wanted to go" (121). Time and again Leila emphasizes that with her air of optimism and positivity, Ona propels all of her loved ones, defying Leon's definition of sorrow as "mov[ing] through the heart the way a ship moves through the ocean [...] One mile forward and eight miles back [...] Inside all of us, Ona's heart still moves forward. Ona's heart is still counting, true and truer to every tomorrow" (145).

The trope of trauma in Bone invites the most ample critical investigation. Juxtaposing different Asian American characters who grapple with the loss of a family member, Christa Baiada notes that all these characters confront a "living death" or "death-in-life" (2007: 2). In Baiada's characterization, this "living death" signifies all kinds of privations and traumas suffered by Asian American characters because of their minority racial or ethnic status - all of which exacerbate the loss of a family member. Baiada identifies a "larger genre of ethnic hauntings and cultural mourning in contemporary literature that does not necessarily rely on supernatural manifestations of the past" (Baiada 2007: 4). She classifies the haunting that takes place in Bone and other trauma suffused narratives as "psychological and emotional, not spectral" (2007: 4). Ona is indeed a haunting presence in Bone although she does not manifest herself literally as a ghost. Allen Gee observes that Leila makes only positive comments about Ona, to the point of eulogizing her (2004: 138). Gee's observation corresponds to Baiada's claim that in the course of the narrative Ona is transformed into "a goddess who guides and inspires the living" (2004: 14). Juliana Chang compares the San Francisco Chinatown of Bone with the San Francisco Chinatown of Louis Chu's Eat a Bowl of Tea, noting that for Ben Loy of Eat a Bowl of Tea it is the site of "regeneration," of a "fresh start," while the San Francisco Chinatown of Bone "proves to be the site of loss and melancholia" (2005: 110-111). Some critics perceive Ona's suicide as an act of defiance, a challenge to the norms of society. Juliana Chang, for example, claims that through her suicide Ona defies temporality. Yoonmee Chang looks at Ona's suicide through the prism of queer studies, arguing that "by killing herself, Ona withdraws from the economy of racial-biological endogamy [...] destroying the body that is commanded to bear endogamous children and ethics" (2010: 103). The idea of violating endogamy gains substance in Ona's case because of her affair with Osvaldo who does not receive the patriarchal acceptance of Ona's father and who is of mixed racial and ethnic origin because his father is Chinese, while his mother is Peruvian, earning him the classification of 
a "mongrel boy" from Leon (Ng 1994: 172). Donald C. Goellnicht traces intertextual origins of Ona's suicide to the No Name Woman's suicide in Maxine Hong Kingston's The Woman Warrior, pointing out that Kingston "paved the way for later Chinese North American women writers to explore further the sensitive subject of suicide" (2000: 301). Goellnicht notes that Fae Myenne Ng takes the trope of suicide in Asian American literature one step further because the No Name Woman's suicide belongs to "rural China," of the pre-Revolution era, while in the present of The Woman Warrior's narrator it exists only symbolically, for example in the form of silence. Ona's suicide takes place in the United States, immediately affecting Leila's family and making a significant erasure in their reality.

\section{Bones}

The trope related to mourning, albeit implying whiteness indirectly, is the trope of bones. Leila associates bones with "memories." For Leila, the very sound of the word "bones" unleashes a welter of memories, a nostalgia for what was lost: "I was surprised how much memory there was in one word" (Ng 1994: 30). Both memories and bones play a parallel role in the narrative, helping to preserve a link between successive generations. Bones, although existing in the material sphere, are primarily a powerful symbol of intergenerational bonds. Memories, although immaterial, create much more tangible links between the living and deceased members of the community. Significant as Leila finds bones, she acknowledges that they are an even more powerful symbol for the first generation Chinese Americans. Some representatives of the first generation believe that bones have power, especially if they were misplaced or forgotten ( $\mathrm{Ng} \mathrm{1994:} \mathrm{88).} \mathrm{That} \mathrm{is} \mathrm{why}$ Leon attributes all of his bad luck, including Ona's suicide, to his paper father, Grandpa Leong's, misplaced bones. Leon promised his paper father to send his bones to China, which he never did. Therefore Grandpa Leong's bones are depicted as "restless" (Ng 50). ${ }^{3}$ Through her writing Leila metaphorically anchors Grandpa Leong's "restless bones" in the bosom of the community and allows them to find peace. The sentence "But in the end the bones remained here" $(\mathrm{Ng}$, Bone, 50) is emblematic because it seems to acknowledge that after Grandpa Leong spent most of his life in the United States, his bones belonged to the country of ascent rather than that of descent, to employ Werner Sollors' terminology (1986: 39).

Misplaced bones and the trope of looking for one's ancestral bones are major tropes in Asian American literature. Both Leon and Leila follow in the footsteps of other Asian American characters searching in vain for ancestral graves. Yet usually those bones and graves remain behind in the country of ancestral descent. If they are misplaced in the United States, it is usually because of the spatial and temporal separation of respective members of immigrant families or their carelessness. In Chang-rae Lee's Native Speaker the first person narrator at one point speaks from the standpoint of an immigrant, who "forgets the ancestral graves 
he has left on a hillside of a faraway land, the loneliest stones that each year go unblessed" (Chang-rae Lee 1995: 279). The theme of forlorn graves comes back in Native Speaker in the Korean songs chanted by a Korean American politician John Kwang. One of the songs tells the story of a young man who leaves his ancestral village and comes back only after years to see his parents dead. The "unblessed," "loneliest stones" correspond to the passage in David Mura's Where the Body Meets Memory, in which the narrator's aunt looks in vain for the grave of her father, who returned to Japan, having spent World War II in an internment camp. In China Men Maxine Hong Kingston speaks of her Chinese ancestors marking the uncharted territory of the United States with their often unmarked graves strewn along the tracks of the Transcontinental Railroad. The narrator of China Men establishes a kind of personal bond with her ancestors while listening to the rustling of the cane in Hawaii; the rustling resembles the whisper of those who once cultivated the soil and who now remain buried underneath. Kingston's reflections on the anonymity of Chinese burial sites overlap with Leon's wondering in Bone where all the Chinese are buried (Ng 1994: 71). He also notes in William Cullen Bryant's "Thanatopsis" - like fashion that there are "more dead than living" (Ng: 71). Leila does not necessarily agree with this characterization, observing that the numbers of the dead and the living depend on who does the counting. Leon sees greater numbers of the dead, while according to Leila, Ona, with her optimistic bent, would see greater numbers of the living.

Chinese immigrants' burial in Bone at the Chinese cemetery rather than an integrated one reflects their minority status and the ghettoization of American society. However, the misplacing of Chinese bones in the United States depicted in Bone cannot be attributed only to the marginalization of Chinese immigrants and forces of oppression that they need to confront, but also to the decisions taken by the deceased Chinese themselves when they were still alive. Most oldtimers "leased' their burial space for only a few years because they hoped to be carried back to China "for a proper burial" $(\mathrm{Ng} 76-77,82) .{ }^{4}$ The Benevolent Association official to whom Leila speaks claims that the oldtimers' graves may initially be forgotten by their relatives, but eventually they come back, often to retrieve the bones, as Leila does. Reflections on the status of Chinese bones are accompanied by a rumination on the scarcity of burial space. ${ }^{5}$ The dead whose grave lease comes to an end are reburied during the solemn ceremony in the Xerox size boxes. Helping Leon to retrieve her paper grandfather's bones and engaging in a proactive search for the bones, Leila in a sense becomes involved in the palimpsestuous reading of her family's history in which she tries to arrive at the original script. Even if the bones cannot be physically retrieved and reburied by the Leong family, the very act of looking and establishing the fate of Grandpa Leong's bones constitutes a kind of valediction of Leila's family's birthright.

Discussing bones in Fae Myenne Ng's novel, it is impossible not to mention the eponymous "bone." In the text proper the term usually appears in the plural, while in the title it is singular. Juliana Chang cites Fae Myenne Ng's explanation of "bone" as "the best metaphor for the enduring quality of the immigrant spirit" 
(Juliana Chang 2005: 118). In American ethnic literature "bone" often stands for the ethnic, cultural core, a kind of essence. Instead of focusing on the essentiality of "bone," $\mathrm{Ng}$ chooses to accentuate its spiritual, transcendent nature, giving the eponymous "bone" a semblance of the "oversoul" encompassing all immigrants. Such a definition of "bone" is in line with the advice that perplexed Leila receives from the Benevolent Association official when she finds out that Grandpa Leong's bones cannot be retrieved: "Bow to the family headstone, it's all the same, the right gesture will find your grandfather" (Ng 1994: 78).

\section{Paper}

Bones as a symbol of intergenerational bonds link firmly to the trope of paper, a very powerful metaphor, implying whiteness indirectly. As a vehicle for the word, paper is a tool of searching for the truth, of commemoration, communication and legitimization. Paper is most explicitly related to Leon as the paper son. Paper is his birthright. Without paper there would be no Leon as the citizen, or even resident of the United States. Nor would there be the next generation of Asian Americans springing from the Leong family. ${ }^{6}$ Therefore it should come as no surprise that Leila declares that "For a paper son paper is blood" (Ng 1994: 61). The price for establishing his paper descent to his paper father, Grandpa Leong, is five thousand dollars. Reflecting on the price of his citizenship, Leon emphasizes the literary and figurative value of paper. Figuratively, paper creates Leon as the citizen of the United States. Literally, paper is precious because of the price tag that comes in the package with the right to enter and stay in the United States. An even higher price tag comes in the form of the broken promises that go unfulfilled in America. A different set of papers is offered to Leon and other paper sons as well as other illegal immigrants - namely naturalization papers in exchange for a confession of illegal entry. Yet Leon does not trust the government and has no intention to stay in the country indefinitely.

Further significance is added to paper by the papers stored in Leon's suitcase. In line with Sarah Dillon's definition of "palimpsests," Leon's papers resemble "lost texts from the past which change the very way we interpret and know that past" (12). Embodying the broken promises of America, they tell the palimpsestuous story of his consistent rejection, materializing through turned down job applications, a rebuffed real estate application and a denied entry into the United States army. Initially surprised that Leon would keep all letters of rejection, Leila concludes that they "marked his endurance" and they showed to what extent he honored time, "American time" ( $\mathrm{Ng} 58)$. Letters of rejection also delineated Leon's history in America and his right to claim American citizenship. Leila's reflections on Leon, her stepfather, to some extent resemble the reflections of a different first person narrator on another Chinese American man. Thinking of her mythical Grandfather, Ah Goong, the narrator of China Men concludes that even if her Grandfather had not purchased citizenship papers, his toil on the railway 
still made him an American. In a similar way, one may infer that Leon's grueling labor in the United States also shows that he "kept his end of the bargain" (Ibid. 103 ) and was worthy of American citizenship. ${ }^{8}$

Leon's suitcase of papers brings to mind another character's briefcase of papers, namely Ralph Ellison's Invisible Man's briefcase to which he clings persistently throughout the novel. Unlike the papers gathered in Leon's suitcase, the papers collected by the Invisible Man mark his nominal success in American society. Realizing that the papers that ostensibly acknowledge his success really are fake tokens of acceptance by the white world, the Invisible Man burns all of them. Burning is not an option in Bone because of the above mentioned reverence for time and because of a "tradition of honoring paper" in line with which "all writing was sacred" (Ng 1994: 58). Paper was firmly related to literacy. If any paper was burned, it was never done in a haphazard fashion, but in accordance with a carefully scripted tradition. All paper inscribed with writing was burned in a temple, while ashes were disposed of in a secret location in the San Francisco Bay. A reverent approach to paper once again links it to bones. Just as the unclaimed bones, remnants of the spent life, are revered and reburied during the solemn ceremony, paper inscribed with writing is approached with reverence and disposed of almost as if it were the remains of a once living human being.

Perusing Leon's papers, Leila identifies herself as a "stepdaughter of a paper son" an heir to a suitcase of lies (Ng 1994: 54). Lies not only represent the broken promises of American reality, but are also closely linked to the stories Leon tells his daughters when they are children. Leon never tells them the truth of constantly being rejected on the grounds of his non-normative racial and ethnic status. Instead he always spins a story that involves some other unfortunate twist of events.

Leon's suitcase of papers triggers Leila's reflections on memory, history and time. Initially ambivalent about the content of the suitcase, she eventually comes to perceive it as an heirloom storing a hoard of memories: "All of it is mine. All I have are those memories, and I want to remember them all" ( $\mathrm{Ng} \mathrm{61).} \mathrm{Leila's}$ conclusion once again brings to mind the Invisible Man's appreciation of the role of all his experiences in the process of identity formation:

all past humiliations became precious parts of my experience, and for the first time ... I began to accept my past. Images of past humiliations flickered through my head and I saw that they were more than separate experiences. They were me; They defined me. I was my experiences and they were me, and no blind men, no matter how powerful they became ... could take that, or change one single itch, taunt, laugh, cry, scar, ache, rage or pain of it. ([1952] 1972: 383)

Both first person narrators acknowledge the formative role of their ordeal. Yet in the case of the Invisible Man the ordeal is different because of a different socio-historical moment, a different kind of marginalization, because it is experienced alone, not in the community and because it leaves a tangible imprint on his body. 
The above quoted passage in which Leila recognizes the importance of her memories complements another excerpt of the novel in which she reflects on the empowering role of retrospection taking place in the course of the narrative enterprise: "Remembering the past gives power to the present" (Ng 88). Remembering is essential in the act of self-formation and in the shaping of the present. Leila's reflections corroborate a claim made by Paul John Eakin, who argues that: "[All] autobiographies are by nature incomplete and they cannot, accordingly, have a definitive shape. As a life changes, so any sense of the shape of a life must change; the autobiographical process evolves because it is part of the life, and the identity of the autobiographical 'I' changes and shifts" (1993: 160). The past connects not only to the present, but also to the future. Another critic of autobiography, Francoise Lionnet, associates autobiographic writing with "see[ing] beyond the constraints of the here and now to the idealized vision of a perfect future" (Lionnet cited in Smith and Watson 1998: 438). With the losses suffered by the Leong family it is difficult to imagine "a perfect future." It is rather more appropriate to speak of a future of relative mental wholeness and integrity resulting from healing that comes after the bridging of the past and the present.

As an instrument of commemoration, communication and storytelling, paper helps to preserve history and the story of a particular family. Narrated in the first person, Leila's narrative is not her personal autobiography, but the autobiography of her entire family. Leila notes that "Family exists because somebody has a story, and knowing the story connects us to a history" (Ng 1994: 36). In her narrative Leila channels the stories of various members of her family, banding them together across time. In the process of the construction of her narrative, she takes under the magnifying glass the lives of her relatives: their motives, their choices as well as their mutual relations to each other. Autobiographies are usually self-analytic undertakings.

In this case instead of looking through herself, Leila strives for a better grasp and illumination of those around her, in particular her sister Ona. Venturing upon the narrative enterprise, she performs an equivalent act to the excavation in which she engages while exploring the papers in Leon's suitcase. The pages of her family's history may be much more difficult to sort than the papers in Leon's suitcase, yet in the very act of searching and telling, she arrives at least at some of the answers, thrashing out intergenerational differences. The text includes a lot of reflection on the ordeal that the first generation went through to secure the future of the second generation, identified by Leila as "the lucky generation" (Ng 1994: 36). What was plain, painful or rut of the day for the generation of Leila's parents is interesting for Leila as a representative of the second generation and as a writer: "To us the deformed man is oddly compelling, the forgotten man is a good story, and a beautiful woman suffers" (Ng 1994: 36). Leila philosophizes about the appeal of difference and trauma when speaking about strangers, but not when speaking about the traumas personally touching her family. Overall, she prioritizes family identification over ethnic identification. When asked by a stranger in a restaurant whether herself and Nina are "two Chinese," she answers "We're two sisters" (Ng 1994: 36). 
The above analysis of the representation of whiteness in Fae Myenne Ng's Bone illustrates a very close overlap between the aesthetic and socio-historical layer of the novel, exemplifying Toni Morrison's statement that writers "transform aspects of their social grounding into aspects of language" (1992: 4). On the level of narrative imagery, whiteness is intricately interwoven with the traumas plaguing the narrator's family. Explicitly, whiteness represents death, mourning, rejection and erasure, entailing marginalization suffered by Chinese Americans because of their non-normative racial and ethnic status. Yet, implicitly, whiteness is also a constituent element of the images which facilitate the process of healing - mainly bones and paper. Narrative imagery involving whiteness contributes to the bridging of the past and the present, forming a bridge between generations, a kind of rivet that allows to at least partly retrieve personal wholeness and recapture the broken promises.

\section{Notes}

1 In The Palimpsest: Literature, Criticism, Theory, Sarah Dillon notes the distinction between "a palimpsest" and "the palimpsest" (11-12). "A palimpsest" denotes the literal use of the word, indicating literally a surface traditionally used for writing, written over more than once and extant until later times. "The palimpsest" signifies the metaphoric use of the term. In a similar vein, Dillon traces the distinction between "palimpsestic" and "palimpsestuous" (4). "Palimpsestic" pertains to "a palimpsest," indicating "the process of layering that produces a palimpsest," while "palimpsestuous" refers to the palimpsest, "describ[ing] the structure that one is presented with as the result of that process, and the subsequent reappearance of the underlying script" (4).

2 The white color is implicitly implied again immediately after Ona's death when Leila in the end leaves the toilet, her momentary place of refuge after hearing the news of Ona's death. She finds the light outside "aggressive" and "hurt[ing]" her eyes (137). Light and the white color have a special connection to each other both in etymology and in the color theory. Ronald W. Casson reconstructs the etymology of the term "white," tracing its derivation from the Indo-European root "kweit," that is, "white, to shine" (227). The Old English reflex of "white" was "hwit," which signified first of all the level of brightness. The hue sense of "hwit" was secondary to brightness, appearing in the following hue denotations:

- "colorless, uncolored" traced back to 888

- hair and complexion color traced back to 900

- snow and milk color traced to 950 (Casson 1997: 227).

Diane C. Le Blanc juxtaposes Grandpa Leong's "restless bones" with Ona's ashes which initially cannot find their place, when Mah moves them around the house (2000: 13).

Donald C. Goellnicht sees the Chinese immigrants' wish to send one's bones back as much more than just a return home. For him, it is a way of "escaping racism" and "a way of regaining 'originary' status and identity they felt they had lost in crossing the Pacific" (2000: 305).

$5 \quad$ Frederick Luis Aldama claims that burial sites 'suggest a ruthless order where people, even the dead, must abide by the rules of capital: when the lease runs out, up come the bones and off they go to the warehouse to await a supply-and-demand redistribution' (Aldama cited in Thomas W. Kim 1999: 47).

6 It is worth mentioning that Leila devotes relatively little attention to explaining the origins of her mother's presence in the United States and dwells on Leon's history as the paper son. 
7 The trope of immigrants' always planning to return to their native country recurs in other literary works featuring immigrants, for example in The Emigrants by Polish playwright Sławomir Mrożek and Maxine Hong Kingston's The Woman Warrior.

8 It is important to also cite other critics' interpretations of Leon as the paper son. Thomas W. Kim looks at Leon as the paper son, Leon the American citizen and Leon as the multivalent subject in terms of an identity performance: "identity is produced by its citation; in other words, the papers will actually produce Leon (44) [...] [Leon's] photos, newspaper clippings, letters, even menus [...] materialize Leon as the product of citation" (45). Leon's history illustrates the impossibility of achieving "authentic" identity and the contingency of identity upon the socio-historical context and the background against which it is interpellated at a particular moment. Juliana Chang notes that papers recovered by Leila from Leon's suitcase are a good exemplification of Lisa Lowe's claim about Bone, on how it "excavate[s] the material histories that have been subjugated or erased" by the official version of history (Chang 2010: 116). A more sinister vision of paper and paper identity emerges from Goellnicht's article, in which he interprets as symbolic suicide the very act of assuming paper identity and giving up at least on paper one's earlier identity. I do not exactly agree with this interpretation because Leon does not really ever renounce any part of his identity. His intention to return to China is the best evidence that he clings to all facets of his identity.

\section{References}

Baiada, Christa (2007) Living death: Loss, mourning, and ethnic renewal in contemporary American fiction. Dissertation Abstract. The City University of New York, iv-16.

Casson, Ronald W. (1997) Color shift: Evolution of English color terms from brightness to hue. Color Categories in Thought and Language. New York: Cambridge University Press, 224-239.

Chang, Juliana (2005) Melancholic remains: Domestic and national secrets in Fae Myenne Ng's Bone. Modern Fiction Studies 51 (1): 110-133.

Chang, Yoonmee (2010) Chinese suicide: Political desire and queer exogamy in Fae Myenne Ng's Bone. Modern Fiction Studies 56 (1): 90-112.

De Bary Nee, Victor and Brett (1973) Longtime Californ': A Documentary Study of an American Chinatown. New York: Pantheon.

Dillon, Sarah (2007) The Palimpsest: Literature, Criticism, Theory. New York: Continuum.

Eakin, Paul John (1993) Malcolm X and the limits of autobiography. African American Autobiography. Englewood Cliffs: Prentice Hall.

Ellison, Ralph (1972) Invisible Man [1952]. New York: Vintage.

Gee, Allen (2004) Deconstructing a narrative hierarchy: Leila Leong's 'I' in Fae Myenne Ng's Bone. MELUS 29 (2): 129-140.

Getz, Joshua M. (1998) Devouring imagery and sense of identity in the 'Oriental' immigrant novel: Joy Kogawa's Obasan, Albert Swissa's The Bound, Fae Myenne Ng's Bone, and Eli Amir's Scapegoat. Dissertation Abstract. The Pennsylvania State University, iii-14.

Goellnicht, Donald C. (2000) Of bones and suicide: Sky Lee's Disappearing Moon Café and Fae Myenne Ng's Bone. Modern Fiction Studies 46 (2), 300-330.

Kim, Thomas W. (1999) 'For a paper son, paper is blood:' Subjectivation and authenticity in Fae Myenne Ng's Bone. MELUS 24 (4): 41-56.

Kingston, Maxine Hong (1986) China Men [1980]. New York: Ballantine Books.

Kingston, Maxine Hong (1977) The Woman Warrior: Memoirs of a Girlhood among Ghosts [1976]. New York: Vintage.

Le Blanc, Diane (2000) Neologism as oppositional language in Fae Myenne Ng's Bone. Rocky Mountain Review, Spring 2000.

Lee, Chang-rae (1996) Native Speaker [1995]. New York: Riverhead. 
Morrison, Toni (1992) Playing in the Dark. Whiteness and Literary Imagination. Cambridge: Harvard University Press.

Mrożek, Sławomir (2003) Emigranci. Warszawa: Oficyna Literacka Noir sur Blanc.

Mura, David (1995) Where the Body Meets Memory: An Odyssey of Race, Sexuality and Identity. New York: Doubleday.

Ng, Fae Myenne (1994) Bone [1993]. New York: Harper Collins.

Smith, Sidonie (1998) Autobiographical manifestos. In: Smith, Sidonie and Julia Watson (eds.) Women, Autobiography, Theory. A Reader. Madison, Wisconsin: University of Wisconsin Press, 433-440.

Sollors, Werner (1986) Beyond Ethnicity: Consent and Descent in American Culture. New York: Oxford University Press.

KLARA SzmaŃKo specializes in American ethnic literature, in particular in African American and Asian American literature. The recurring tropes of her publications are: whiteness, invisibility, visibility, visual dynamics, power dynamics, transformational identity politics, multiculturalism, representation of space, mimicry, nationalism and gender relations. She is also the author of Invisibility in African American and Asian American Literature: A Comparative Study (McFarland \& Company 2008) and Visions of Whiteness in Selected Works of Asian American Literature (McFarland \& Company 2015). She did her M.A. (2002) as well as Ph.D. (2005) at the University of Wrocław and her habilitation at the University of Łódź in 2016. She is Associate Professor at the Institute of English Studies, Department of American Literature and Culture, University of Opole.

Address: Dr hab. Klara Szmańko (D. Litt.), Institute of English Studies, Department of American Literature and Culture, University of Opole, pl. Kopernika 11 45-040 Opole, Poland. [email: klarka@op.pl] 
